Artikel Penelitian

\title{
Efektivitas Larvasida Granul Ekstrak Etanol Daun Pisang Nangka (Musa x paradisiaca L.) terhadap Larva Nyamuk Aedes aegypti
}

\section{Effectiveness of Musa x paradisiaca L. Leaves' Ethanol Extract Granule Larvicide against Aedes aegypti Larvae}

\author{
Anna Yuliana ${ }^{1 *}$, Rusdi Aris Rinaldi ${ }^{1}$, Nur Rahayuningsih ${ }^{1}$, Firman Gustaman ${ }^{1}$
}

Kutipan: Yuliana A, Rinaldi RA, Rahayuningsih N, Gustaman F. Efektivitas Larvasida Granul Ekstrak Etanol Daun Pisang Nangka (Musa $x$ paradisiaca $\mathrm{L}$.) terhadap Larva Nyamuk Aedes aegypti. ASP. Juni 2021:13(1): 69-78

Editor: Firda Yanuar P. Diterima: 06 November 2020 Revisi: 23 April 2021

Layak Terbit: 09 Juni 202

Catatan Penerbit: Aspirator tetap netral dalam hal klaim yurisdiksi di peta yang diterbitkan dan afiliasi kelembagaan. Pemegang lisensi Loka Litbangkes Pangandaran, Indonesia. Artikel ini adalah artikel dengan akses terbuka yang didistribusikan dengan syarat dan ketentuan lisensi Creative Commons Attribution Share-Alike (CC BY SA) (https:/ creativecommons.org/licenses/by$\mathrm{sa} / 4.0 /)$

*Korespondensi Penulis.

Email: anna_yuliana@stikes-bth.ac.id
${ }^{1}$ Department of Pharmacy STIKes Bakti Tunas Husada, Tasikmalaya, Jawa Barat

Abstract. Musa x paradisiaca L. leaves are known to contain phenols, flavonoids, saponins, tannins, and other compounds that can be used as larvicides. This study aims to determine the effect of Musa $\mathrm{x}$ paradisiaca $L$ leaves' ethanol extract granules on the mortality of Aedes aegypti larvae. The Research was experimental in two stages of effectiveness testing, that are extract and granule formula effectiveness test. Data were analyzed using the Kruskal-Wallis test and the Mann-Whitney test. The extraction method used was maceration using $96 \%$ ethanol. The concentration of the extract dosage used were $0.2 ; 0.5 ; 1 ; 2 ;$ and $4 \%$, with control (+) temephos and control (-). Repetitions were carried out 3 times with a sample total of 675 larvae. Observations were made for 12 and 24 hours. Preparation of granules using 2 formulas, formula 1 granules without extract and formula 2 granules with the extract. To fulfill the granule formulation criteria, the preparation was evaluated. The results showed that the concentration of $4 \%$ extract was the most effective at $98.7 \%$, as stated by the Kruskal-Wallis test result, p-value $<0.05$, which means that there was an effect on the effectiveness of larvicide. The percentage of mortality of larvae given formula 2 is $100 \%$ and based on the Mann-Whitney test with value $p<0.05$, there is a difference between granule 1 and 2 formula. Criteria of granule including moisture content $(1.72 \%)$, angle of rest $24^{\circ}$, flow velocity $(50 \mathrm{gr} / \mathrm{sec})$, and dispersion time (2.25 minutes). The granular formula of Musa x paradisiaca L leaves can make the application easier and hopefully can be used as effectively as synthetic larvicide in the community.

Keywords: Musa x paradisiaca L, Ethanol extract, larvicide effectivity, Aedes aegypti

Abstrak. Daun Musa x paradisiaca L diketahui mengandung fenol, flavonoid, saponin, tanin dan senyawa lainnya yang mampu berperan sebagai larvasida. Penelitian ini bertujuan untuk mengetahui pengaruh granul ekstrak etanol daun pisang nangka terhadap kematian larva Aedes aegypti. Penelitian bersifat eksperimental melalui dua tahapan uji efektivitas yaitu uji efektivitas ekstrak dan uji efektivitas formulasi granul. Data dianalisis dengan uji KruskalWallis dan uji Mann-Whitney. Metode ekstraksi yang digunakan adalah maserasi menggunakan etanol 96\%. Konsentrasi ekstrak yang digunakan adalah 0,2; 0,5; 1; 2; dan 4\%, dengan kontrol (+) temephos dan kontrol (-). Pengulangan dilakukan sebanyak 3 kali dengan total sampel 675 larva. Pengamatan dilakukan selama 12 dan 24 jam. Pembuatan granul menggunakan 2 formulasi yaitu formulasi 1 berupa granul tanpa ekstrak dan formulasi 2 granul dengan konsentrasi ekstrak efektif. Untuk memenuhi kriteria formulasi granul dilakukan evaluasi sediaan. Hasil penelitian menunjukan konsentrasi ekstrak $4 \%$ paling efektif membunuh sebesar 98,7\% larva, analisis Kruskal-Wallis menunjukan nilai $p<0,05$ yang berarti bahwa konsentrasi larvasida berpengaruh terhadap kematian larva. Persentase kematian larva menunjukkan hasil adanya perbedaan nyata antara formulasi 1 dan formulasi $2(p<0.05)$. Formula granul yang dibuat telah memenuhi persyaratan kriteria granul meliputi kadar lembap (1,72\%), sudut istirahat $24^{\circ}$, kecepatan alir (50 gr/detik) dan waktu dispersi (2,25 menit). Formulasi granul ekstrak daun pisang nangka dapat memudahkan pengaplikasian sehingga diharapkan dapat digunakan secara efektif seperti penggunaan larvasida sintetis di masyarakat.

Kata Kunci: Daun pisang nangka, ekstrak etanol, efektivitas larvasida, Aedes aegypti 


\section{PENDAHULUAN}

Demam Berdarah Dengue (DBD) merupakan penyakit yang ditularkan melalui vektor nyamuk dan sampai saat ini masih menjadi salah satu masalah kesehatan di masyarakat. Kasus DBD pertama kali di Indonesia dilaporkan terjadi di daerah Surabaya dan Jakarta. Angka kasus DBD secara nasional pada tahun 2016 sebesar 78,85/100.000 penduduk, dengan jumlah tertinggi terjadi di Provinsi Bali, Kalimantan Timur dan DKI Jakarta. Selanjutnya terjadi penurunan angka kasus pada 2017 menjadi 22,5/100.000 penduduk. Di Indonesia ada beberapa wilayah yang merupakan daerah endemis DBD, salah satunya adalah Provinsi Jawa Barat.

Provinsi Jawa Barat terdiri dari 27 kabupaten/kota dan seluruhnya telah melaporkan kejadian virus dengue. Sejak 2004, sebanyak 25 kabupaten/kota sudah menjadi wilayah endemis dengue, hanya Kabupaten Bandung Barat dan Pangandaran yang belum melaporkan kejadian infeksi virus dengue karena kedua kabupaten tersebut merupakan kabupaten baru hasil pemekaran wilayah. Data Dinas Kesehatan Provinsi Jawa Barat menunjukan puncak kasus tertinggi terjadi pada tahun 2009 dengan jumlah kematian (case fatality rate/CFR) tertinggi, yakni 0,81\%. Fluktuasi angka insidensi (incidence rate/ IR) dan CFR di Jawa Barat hampir memiliki pola yang sama, yakni peningkatan kasus diikuti dengan peningkatan CFR atau sebaliknya. Kasus dengue periode 2004-2017 (14 tahun) telah mengalami penurunan pada 2011, 2014, dan 2017. Kasus terendah terjadi pada 2017 dengan IR 24,08/100.000 penduduk. Angka kematian dengue pada tahun 2004-2006 masih di atas 1\%. Angka ini berhasil ditekan pada tahun-tahun berikutnya hingga dibawah $1 \%$ sesuai dengan target nasional. Sementara CFR terendah terjadi pada tahun 2011 yakni sebesar $0.42 \%$. Pada periode 2012 dan 2014, terdapat lima kota yang menyumbang jumlah kasus tertinggi yaitu, Sukabumi, Bandung, Tasikmalaya, Cimahi, dan Bogor.

Sampai tahun 2018, kejadian infeksi virus dengue masih banyak ditemukan di wilayah perkotaan. Beberapa kota masih menjadi penyumbang terbesar, yaitu Kota Bandung, Kota Sukabumi, dan Kota Bogor. Perkembangan kasus DBD per kabupaten/ kota di Provinsi Jawa Barat menunjukkan angka yang fluktuatif, selama 2016-2018 terjadi penurunan jumlah kasus, namun pada awal 2019 beberapa wilayah melaporkan adanya peningkatan jumlah kasus infeksi virus dengue. Berdasarkan data dari Direktorat Jenderal Pencegahan dan Pengendalian Penyakit Menular Kementerian Kesehatan RI, per 1 Februari 2019 angka kejadian DBD di Provinsi Jawa Barat adalah sebanyak 2204 kasus dengan 14 kematian. ${ }^{1}$

Aedes aegypti merupakan salah satu vektor penular DBD yang banyak ditemukan di lingkungan rumah. Pengendalian populasi vektor dalam hal ini Ae. aegypti sangat penting dilakukan untuk mencegah penularan DBD. ${ }^{2}$ Salah satu cara untuk memutus siklus vektor adalah dengan menggunakan larvasida. Larvasida merupakan metode pemberantasan yang paling banyak digunakan karena memiliki beberapa kelebihan yaitu pengaplikasian mudah, hasilnya cepat, efektivitas tinggi selama tidak ada resisten, mudah diperoleh dan biayanya murah. Larvasida yang biasa digunakan biasanya adalah larvasida sintetis dengan kandungan zat aktif temephos. ${ }^{3}$

Penggunaan larvasida sintetis dalam jangka panjang ternyata dapat menyebabkan efek samping yang merugikan. Meskipun efektif dalam membunuh larva, larvasida sintetis dapat menyebabkan organisme lain yang tidak ditargetkan juga ikut terbunuh. ${ }^{4}$ Selain itu penggunaan larvasida sintetis secara terus menerus dan dalam jangka waktu lama dapat menyebabkan vektor menjadi resisten. Munculnya resistensi Temephos ${ }^{\circledast}$ sudah terjadi di beberapa tempat diantaranya di Provinsi Banten, Kota Demak, Surabaya ${ }^{2}$, dan Tasikmalaya. ${ }^{5}$ Berdasarkan fenomena tersebut, diperlukan alternatif lain yang dapat menggantikan peran larvasida sintetis tetapi tidak memiliki efek samping yang kurang baik bagi lingkungan maupun bagi vektor itu sendiri. ${ }^{6}$ 
Penggunaan larvasida alami memiliki risiko yang lebih rendah dibandingkan dengan pemakaian larvasida sintetis. Beberapa kelebihan dari penggunaan larvasida alami adalah toksisitas rendah terutama pada mamalia, mampu terdegradasi oleh sinar matahari, udara, dan kelembapan. ${ }^{7}$ Larvasida dari bahan alami telah terbukti memberikan kontribusi yang bermakna sebagai alternatif baru dalam upaya menurunkan jumlah vektor nyamuk. ${ }^{8}$

Penelitian berkaitan dengan larvasida alami telah banyak dilakukan terutama dari tanaman dengan kandungan senyawa yang berfungsi sebagai larvasida. Senyawa yang terkandung dalam tanaman dan bersifat sebagai larvasida adalah golongan fenol, flavonoid, tannin, saponin, monoterpen dan seskuiterpen. ${ }^{9}$ Berdasarkan penelitian pada tanaman pepaya (Carica papaya L) ${ }^{10}$, rambutan (Nephelium lappaceum L.) ${ }^{11}$, sirsak (Annona muricata $)^{11}$, serai wangi (Cymbopogon nardus $\left.L\right)^{12}$, limau (Citrus amblycarpa $)^{13}$ dan sengkuang (Dracontomelon dao $)^{14}$, senyawa fenol, flavonoid, tanin, dan saponin terbukti efektif membunuh larva Aedes aegypti.

Salah satu tanaman yang jarang termanfaatkan dan sering menjadi limbah adalah daun pisang (Musa textilis Née.). Senyawa fenol, flavonoid, dan tanin yang terkandung dalam pisang dapat bersifat sebagai bakterisida dan fungisida. Penelitian Mambang pada tahun 2018 menyebutkan bahwa daun pisang mempunyai efektivitas antibakteri terhadap Staphylococcus aureus. ${ }^{15}$ Daun pisang juga dapat bersifat sebagai fungisida karena dapat mengendalikan pertumbuhan jamur patogen pada tanaman tomat. ${ }^{16}$ Penelitian dengan melakukan penapisan kandungan senyawa kimia daun pisang dan melakukan uji efektivitas larvasida terhadap larva Aedes aegypti perlu dilakukan untuk mengetahui potensi daun pisang sebagai larvasida.

Daun pisang yang digunakan dalam penelitian ini adalah daun pisang nangka (Musa $x$ paradisiaca L). Pemilihan daun pisang nangka karena di daerah Sukadana Kabupaten Ciamis daun pisang nangka jarang dimanfaatkan dan sering menjadi limbah ketika pohon pisang ditebang. Penelitian ini diharapkan dapat membuktikan manfaat dari daun pisang sebagai larvasida alami. Manfaat lain yang diharapkan adalah untuk mengurangi limbah daun yang tidak termanfaatkan serta dapat menambah nilai dari daun pisang nangka baik secara ekonomis maupun manfaatnya. Selain dilakukan uji efektivitas dari ekstrak daun pisang, penelitian ini juga mengembangkan formulasi sediaan granul dari ekstrak untuk memudahkan aplikasi di masyarakat. ${ }^{7}$

\section{BAHAN DAN METODE}

\section{Lokasi dan Waktu Penelitian}

Larva Aedes aegypti diperoleh dari Loka Penelitian dan Pengembangan Kesehatan Pangandaran. Daun pisang nangka (Musa x paradisiaca L) diambil dari daerah Sukadana Kabupaten Ciamis. Taksonomi tanaman daun pisang diketahui dengan melakukan determinasi di Herbarium Jatinangor Laboratorium Taksonomi Tumbuhan Departemen Biologi FMIPA Universitas Padjadjaran Bandung. Secara keseluruhan, proses penelitian ini dilaksanakan pada Januari - Juli 2020 bertempat di Laboratorium Kimia STIKes BTH Tasikmalaya.

\section{Populasi dan Sampel Penelitian}

Larva yang digunakan pada penelitian ini adalah larva instar III yang relatif stabil dari pengaruh faktor eksternal serta memiliki daya tahan hidup yang kuat. Larva diambil dalam dua periode. Periode pertama sebanyak 525 larva dimasukan kedalam 7 transfer bag untuk selanjutnya dibawa menuju Laboratorium Kimia STIKes BTH Tasikmalaya. Periode ini digunakan untuk uji efektivitas ekstrak. Periode kedua sebanyak 150 larva dalam 2 transfer bag diambil untuk uji formulasi granul melalui proses yang sama seperti 
periode pertama. Dilakukan dua periode karena pembuatan ekstrak dan formulasi granul ada perbedaan rentang waktu selama 2 minggu.

Proses seleksi larva dilaksanakan di Loka Litbangkes Pangandaran dengan bantuan petugas laboratorium yang telah berpengalaman. Larva yang dibawa ke laboratorium adalah larva yang telah sesuai stadium dan ukurannya relatif sama. Selanjutnya masingmasing 25 larva dipindahkan ke dalam 7 gelas kimia ukuran $250 \mathrm{~mL}$ dan dilakukan uji efektivitas ekstrak daun pisang nangka dengan konsentrasi 0,2; 0,5; 1 ; ; dan 4\%, kontrol (+) Temephos ${ }^{\circledR}$ dan kontrol (-) tanpa zat aktif. Total volume keseluruhan penambahan ekstrak dan air adalah $100 \mathrm{~mL}$.

\section{Pembuatan Ekstrak Etanol Daun Pisang Nangka}

Daun pisang nangka yang dipilih adalah daun pisang yang sudah tua ditandai dengan warna hijau tua dan berada di bagian paling bawah. Daun yang digunakan dipilih daun yang sehat, bebas hama dan tidak rusak/segar. Daun pisang dipisahkan dari batangnya kemudian dicuci dan dikeringkan dibawah sinar matahari. Setelah kering daun pisang disortasi kembali dari tanah atau debu yang menempel. Bagian daun yang busuk dan berjamur dibuang. Daun pisang yang sudah kering dihaluskan dengan blender sehingga dihasilkan serbuk daun pisang nangka. ${ }^{17}$

Metode ekstraksi yang digunakan adalah metode maserasi dengan tujuan untuk meminimalisir pemanasan yang dapat merusak senyawa metabolit sekunder yang bersifat termolabil. Sebanyak $1,3 \mathrm{~kg}$ simplisia serbuk daun pisang nangka dimaserasi dengan etanol 96\% sebanyak 1 liter, diaduk dan kemudian dibiarkan dalam waktu 48 jam dengan penggantian pelarut setiap 24 jam. Etanol dipilih karena bersifat semipolar sehingga diharapkan dapat menarik senyawa metabolit sekunder lebih banyak dan memiliki tingkat toksisitas lebih rendah dibandingkan golongan alkohol yang lain. Hasil ekstrak cair diuapkan dengan Rotary evaporator sehingga diperoleh ekstrak kental daun pisang yang akan dilanjutkan pada tahap pembuatan granul.?

Volume ekstrak daun pisang yang diperoleh dapat dihitung berdasarkan rumus berikut.

$$
\text { Jumlah Ekstrak }(\%)=\frac{\text { Bobot ekstrak kental }}{\text { Bobot simplisia }} \times 100 \%
$$

Penapisan fitokimia dilakukan untuk mengetahui kandungan metabolit sekunder dari ekstrak daun pisang nangka.

\section{Pembuatan Sediaan Granul dari Ekstrak Etanol Daun Pisang Nangka}

Formula larvasida granul ekstrak etanol daun pisang nangka yang diujikan yaitu formulasi 1 tidak mengandung ekstrak daun pisang dan formulasi 2 ditambahkan ekstrak etanol daun pisang nangka. Pada proses pembuatan formulasi granul ini, selain ekstrak ditambahkan pula PVP (Polivinil Pirolidon) sebagai pengikat dan laktosa yang berfungsi sebagai pengisi granul.

Tabel 1. Formulasi Granul Ekstrak Etanol Daun Pisang Nangka

\begin{tabular}{lcc}
\hline \multicolumn{1}{c}{ Nama Bahan } & Formula 1 & Formula 2 \\
\hline Ekstrak etanol daun pisang (gram) & 0 & $\begin{array}{c}\text { Diambil } \\
\text { paling efektif sebagai larvasida }\end{array}$ \\
PVP (\%) & 2 & 2 \\
Laktosa (gram) & 20 & 20 \\
\hline
\end{tabular}

Evaluasi granul, meliputi uji kadar lembab, sudut istirahat, kecepatan alir dan uji waktu dispersi, dilakukan untuk mengetahui kualitas granul yang diperoleh. ${ }^{18}$ 


\section{Uji Efektivitas terhadap Larva Aedes aegypti}

Lima konsentrasi berbeda dari ekstrak etanol daun pisang yang diujikan yaitu $0,25 \%$; 0,5\%; $1 \% ; 2 \%$; dan 4\% . Selain itu, disiapkan juga kontrol positif dengan penambahan larvasida sintetis temephos $0,25 \%$ dan kontrol negatif yang tidak ditambahkan apapun. Larva disiapkan dalam 7 wadah berbeda dengan masing-masing wadah diisi 25 larva. Pengamatan dilakukan selama 12 dan 24 jam dengan 3 kali pengulangan. Pemantauan larva dilakukan dengan melihat jumlah larva yang mati, ditandai dengan larva tenggelam atau tidak bergerak saat disentuh batang pengaduk. Persentase mortalitas larva dihitung dengan rumus berikut: ${ }^{1,4}$

$$
\text { Persentase Mortalitas }(\%)=\frac{\text { Jumlah larva mati }}{\text { Jumlah larva uji }} \times 100 \%
$$

Hasil perhitungan dengan rumus di atas akan menunjukkan konsentrasi efektif yang dapat membunuh larva. Nilai konsentrasi ini yang kemudian dijadikan dasar dalam pembuatan sediaan granul.

Pengujian efektivitas granul dilakukan dengan menyiapkan 2 wadah, yaitu wadah 1 berisi granul formulasi 1 (PVP dan laktosa) dan wadah 2 berisi granul formulasi 2 (ekstrak, PVP, dan laktosa). Sebanyak 20 gram granul dilarutkan dalam $100 \mathrm{~mL}$ air lalu tiap wadah tersebut ditambahkan masing-masing 25 larva Aedes aegypti. Kemudian ditentukan persentase mortalitas larva pada 12 dan 24 jam. Pengulangan dilakukan sebanyak tiga kali.

\section{Analisis Data}

Penentuan pengaruh pemberian granul ekstrak etanol daun pisang nangka terhadap kematian larva dilakukan dengan analisis menggunakan metode rangkaian uji independent sample t-test yang dilanjutkan dengan uji Kruskall-Wallis dan MannWhitney melalui software SPSS® versi 15.00.

\section{HASIL}

Berdasarkan hasil determinasi melalui surat Lembar Identifikasi Tumbuhan Nomor 047/HB/02/2020, tanaman yang dipakai telah sesuai identitasnya yaitu daun pisang nangka dengan nama ilmiah Musa x paradisiaca $L$ dan termasuk famili Zingiberaceae. Total ekstrak kental sebesar 3,14\% yang didapatkan dari $1.3 \mathrm{~kg}$ simplisia kering daun pisang nangka. Berdasarkan hasil penapisan fitokimia, ekstrak daun pisang nangka mengandung metabolit sekunder flavonoid, tanin, polifenol, saponin, monoterpen dan seskuiterpen. Dilakukan juga uji bebas etanol untuk meyakinkan bahwa ekstrak sudah tidak mengandung etanol yang dikhawatirkan akan mengganggu proses pengujian larvasida. Hasil penapisan fitokimia dapat dilihat pada Tabel 2.

Tabel 2. Hasil Skrining Fitokimia Ekstrak Etanol Daun Pisang Nangka*

\begin{tabular}{lc}
\multicolumn{1}{c}{ Senyawa } & Hasil \\
\hline Alkaloid & - \\
Flavonoid & + \\
Tanin dan polifenol & + \\
Saponin & + \\
Monoterpen dan Seskuiterpen & + \\
Steroid dan Triterpenoid & - \\
Kuinon & - \\
Etanol & - \\
\hline
\end{tabular}

*+ Positif mengandung senyawa

- Negatif tidak mengandung senyawa 
Uji efektivitas larvasida ekstrak etanol daun pisang nangka memperoleh hasil bahwa konsentrasi paling efektif untuk membunuh larva adalah konsentrasi $4 \%$ yang ditunjukan dengan persentase kematian larva paling besar (rata-rata kematian larva 98,7\%). Hasil Uji efektivitas ekstrak daun pisang dapat dilihat pada Tabel 3.

Tabel 3. Hasil Uji Efektivitas Larvasida Ekstrak Daun Pisang Nangka*

\begin{tabular}{lccc} 
Konsentrasi & $\begin{array}{c}\text { Kematian Larva } \\
\text { 12 Jam }\end{array}$ & $\begin{array}{c}\text { Kematian Larva } \\
\text { 24 Jam }\end{array}$ & $\begin{array}{c}\text { Rata - Rata } \\
\text { \% Kematian Larva }\end{array}$ \\
\hline Kontrol + & $12,5 \pm 0,58$ & $25 \pm 0$ & 100,0 \\
Kontrol - & $0 \pm 0$ & $0 \pm 0$ & 0,0 \\
$0,25 \%$ & $0 \pm 0$ & $2,7 \pm 1,5$ & 10,7 \\
$0,5 \%$ & $0 \pm 0$ & $6 \pm 1$ & 24,0 \\
$1 \%$ & $3 \pm 1,5$ & $10 \pm 1$ & 40,0 \\
$2 \%$ & $3,3 \pm 2,3$ & $14,7 \pm 0,6$ & 58,7 \\
$4 \%$ & $12,7 \pm 0,6$ & $24,7 \pm 0,6$ & 98,7 \\
\hline
\end{tabular}

*dilakukan 3 kali pengulangan

** tulisan yang ditebalkan merupakan konsentrasi paling efektif

Konsentrasi $4 \%$ kemudian dijadikan acuan dalam pembuatan sediaan granul larvasida. Hasil evaluasi sediaan granul menunjukan bahwa granul memenuhi persyaratan untuk semua parameter. Hasil evaluasi granul dapat dilihat pada Tabel 4.

Tabel 4. Hasil Evaluasi Granul Ekstrak Etanol Daun Pisang Nangka*

\begin{tabular}{|c|c|c|}
\hline Parameter & Hasil & Persyaratan \\
\hline Kadar lembab (\%) & 1.72 & $2-4$ \\
\hline Sudut istirahat ${ }^{\circ}$ & 24 & $<25$ (sangat baik) \\
\hline Kadar alir (gram/detik) & $50 / 3$ & $>10 / 1$ \\
\hline Waktu dispersi (menit) & 2.25 & $<5$ \\
\hline
\end{tabular}

*dilakukan 3 kali pengulangan

Hasil uji efektivitas granul ekstrak etanol pisang nangka menunjukan bahwa formulasi 2 (dengan kandungan ekstrak daun pisang nangka) dapat mematikan semua larva dalam waktu 24 jam. Formula 1 adalah granul tanpa ditambahkan ekstrak, hanya berisi PVP dan laktosa. Formula 1 dijadikan kontrol untuk mengetahui apakah bahan kimia yang ditambahkan dalam pembuatan granul memiliki efek membunuh larva atau tidak. Berdasarkan hasil pada Tabel 5 dapat dilihat bahwa formulasi 1 tidak menyebabkan kematian larva dengan persentase mortalitas $0 \%$.

Tabel 5. Hasil Uji Efektivitas Larvasida Granul Ekstrak Etanol Daun Pisang Nangka*

\begin{tabular}{cccc}
\hline Formula & $\begin{array}{c}\text { Kematian Larva } \\
\text { 12 Jam }\end{array}$ & $\begin{array}{c}\text { Kematian Larva } \\
\text { 24 Jam }\end{array}$ & $\begin{array}{c}\text { Rata - Rata } \\
\text { \% Kematian Larva }\end{array}$ \\
\hline 1 & $0 \pm 0$ & $0 \pm 0$ & 0 \\
$2^{* *}$ & $\mathbf{1 2} \pm \mathbf{0}$ & $\mathbf{2 5} \pm \mathbf{0}$ & $\mathbf{1 0 0}$ \\
\hline
\end{tabular}

*dilakukan 3 kali pengulangan

** tulisan yang ditebalkan merupakan konsentrasi paling efektif

Hasil uji statistik efektivitas larvasida ekstrak etanol daun pisang nangka menunjukan data bersifat homogen namun tidak berdistribusi normal sehingga dilakukan uji Kruskal-Wallis dan Mann-Whitney. Hasil analisis menunjukkan $\mathrm{p}<0,05$ yang berarti ada perbedaan signifikan jumlah kematian larva pada setiap konsentrasi. Uji Mann-Whitney menunjukan adanya perbedaan kematian larva yang signifikan antara formulasi 1 dan formulasi $2(\mathrm{p}<0,05)$.

\section{PEMBAHASAN}

Daun pisang diketahui mengandung saponin dan fenolik yang biasa dimanfaatkan 
sebagai antibakteri dan juga larvasida. Berdasarkan hasil penapisan fitokimia, daun pisang nangka mengandung flavonoid, tanin, polifenol, saponin, monoterpen dan seskuiterpen. ${ }^{19}$ Uji etanol dilakukan dengan menambahkan asam asetat dan asam sulfat untuk memastikan bahwa ekstrak tidak mengandung etanol. Etanol diketahui dapat berperan sebagai antibakteri dan memiliki kemampuan untuk mematikan mikroorganisme, jika ekstrak masih mengandung etanol maka dikhawatirkan dapat mengganggu proses uji larvasida. ${ }^{20}$

Sebanyak 98,7\% larva uji mati pada konsentrasi 4\%. Hasil uji menunjukan bahwa semakin tinggi konsentrasi ekstrak maka semakin tinggi persentase mortalitas larva. Pada uji formulasi granul, didapatkan hasil kematian sebanyak 100\% sementara pada formulasi tanpa ekstrak tidak ada kematian larva. Hal ini menunjukan bahwa formulasi granul efektif untuk digunakan sebagai formulasi larvasida khususnya pada ekstrak daun pisang. Dibandingkan dengan hasil uji yang lain, formulasi granul ekstrak daun pisang termasuk salah satu kandidat potensial untuk dikembangkan sebagai larvasida hayati. ${ }^{21}$

Hasil penapisan fitokimia ekstrak daun pisang nangka menunjukan hasil positif untuk flavonoid, polifenol, tanin, saponin, monoterpen dan sesquiterpen yang berdasarkan hasil penelitian sebelumnya diketahui bersifat sebagai insektisida dan fungisida. ${ }^{22}$ Kandungan senyawa flavonoid pada ekstrak daun pisang nangka berperan dalam menghambat/mengganggu sistem pernapasan, dengan jalan menghambat enzim $\mathrm{NAD}+$ dan koenzim Q. Flavonoid merupakan racun kontak yang memberikan efek menghambat sistem pernafasan dan mengganggu sistem saraf nyamuk. ${ }^{23}$ Kandungan saponin dalam ekstrak daun pisang nangka berperan mengikat sterol bebas pada organ pencernaan larva. Sterol memfasilitasi enzim ekdison melalui mekanisme pengelupasan atau pergantian kulit larva, jika sterol terikat maka hormon ekdison tidak akan terbentuk dan larva tidak akan mengalami pergantian kulit sehingga larva tidak dapat tumbuh dan menyebabkan kematian. Apabila saponin kontak dengan permukaan kulit nyamuk akan merusak mukosa kulit dan mengakibatkan hemolisis darah. ${ }^{24}$ Kandungan senyawa tanin dalam ekstrak dapat mengurangi nafsu makan larva dengan jalan menghambat pembentukan enzim pencernaan larva sehingga lama kelamaan larva akan mati. ${ }^{25}$

Terjadinya kematian larva pada semua konsentrasi kelompok perlakuan sebagai akibat terjadinya kontak senyawa aktif yang terkandung pada ekstrak daun pisang nangka dengan larva. Hal ini diakibatkan masuknya senyawa alami yang terkandung dalam ekstrak ke dalam tubuh larva. Semakin tinggi konsentrasi ekstrak, maka semakin banyak larva yang mengalami kematian. Hasil pengamatan menggunakan mikroskop, larva yang mengalami kematian akibat kontak dengan ekstrak daun pisang nangka memiliki ciri-ciri berupa larva tidak bergerak sama sekali bila disentuh, larva berwarna putih dengan bentuk memanjang, kaku dan tenggelam.

Penelitian sebelumnya mengenai efektivitas larvasida dari beberapa tanaman yang telah dilakukan di antaranya yaitu daun pepaya (Carica papaya L.), yang memiliki nilai mortalitas 5\% pada konsentrasi ekstrak 15\% ; ekstrak daun sengkuang (Dracontomelon dao) dengan mortalitas 38\% pada konsentrasi $2 \%{ }^{14}$; ekstrak daun serai wangi (Cymbopogon nardus L) menghasilkan konsentrasi efektif sebesar 1,25\% dengan nilai mortalitas $52 \% .{ }^{12}$ Hasil-hasil penelitian tersebut menunjukan bahwa ekstrak etanol daun pisang nangka memiliki efektivitas lebih besar dengan nilai persentase mortalitas paling tinggi.

Proses granulasi bertujuan untuk meningkatkan aliran ekstrak daun pisang nangka dengan jalan membentuknya menjadi bulatan-bulatan dalam bentuk yang beraturan. ${ }^{18}$ Karakteristik ekstrak kental yang sulit untuk diaplikasikan dalam percobaan menjadi lebih mudah dengan bentuk granul. Sediaan granul dapat diproduksi dalam jumlah banyak dan dapat dijadikan salah satu alternatif pengganti larvasida sintetis .

Penggunaan ekstrak dan granul dalam proses penelitian sebagai larvasida sangat 
berpengaruh dalam kemudahan pemakaian. Formula granul lebih mudah untuk diambil dan dilarutkan dalam air sementara dalam bentuk ekstrak kental terdapat sedikit kesulitan dalam proses pengambilannya, selain itu daya larut ekstrak lebih sulit dibandingkan dengan granul. Pembuatan formulasi granul ekstrak etanol daun pisang nangka diharapkan dapat mempermudah dalam aplikasi sehari-hari terutama dalam pengembangannya sebagai larvasida komersial.

\section{KESIMPULAN}

Ekstrak etanol daun pisang nangka memiliki efektivitas cukup baik sebagai larvasida terhadap Aedes aegypti. Formulasi granul ekstrak daun pisang nangka dapat memudahkan pengaplikasian sehingga diharapkan dapat digunakan secara efektif seperti penggunaan larvasida sintetis di masyarakat

\section{UCAPAN TERIMA KASIH}

Terima kasih kepada LPPM STIKes BTH untuk dukungan dana dan fasilitas penelitian. Ucapan terima kasih juga disampaikan kepada Laboratorium Loka Litbangkes Pangandaran yang telah membantu pelaksanaan proses penelitian sehingga bisa berlangsung dengan lancar.

\section{KONTRIBUSI PENULIS}

Pada artikel ini, Anna Yuliana, Rusdi Aris Rinaldi, Nur Rahayuningsih, dan Firman Gustaman berperan sebagai kontributor utama. Kontribusi setiap penulis dapat dilihat pada rincian berikut ini.

Konsep; Kurasi Data; Pemrograman; Visualisasi $\quad: \quad$ RAR Analisis Data; Sponsor Pendanaan; $\quad$ : NR

Investigasi $\quad:$ FG

Metodologi; Manajemen Proyek; Sumber Daya $\quad$ : AY

Supervisi; Validasi $\quad: \quad$ AY, NR

Menulis- Pembuatan Draft $\quad: \quad$ AY, RAR

Menulis-Mengkaji $\quad: \quad$ AY, RAR, NR, FG

dan Mengedit

\section{DAFTAR RUJUKAN}

1. Suwandono A, Ipa M, Astuti EP, Wahono T, Prasetyowati H, Fuadzy H, Widawati M, Hendri J, Ruliansyah A, Fuadiyah ME, Pradani FY. M. Dengue update: Menilik perjalanan dengue di Jawa Barat. LIPI Press. 2019. 1-14

2. Riyadi Z, Julizar J, Rahmatini R. Uji efektivitas ekstrak etanol biji rambutan (Nephelium lappaceum L.) sebagai larvasida alami pada larva nyamuk Aedes aegypti. Jurnal Kesehatan Andalas. 2018 Jun 10;7(2): 3-9

3. Pamungkas RW, Syafei NS, Soeroto AY. perbandingan efek larvasida minyak atsiri daun cengkeh (Syzygium aromaticum L.) varietas zanzibar dengan temephos terhadap larva nyamuk Aedes aegypti. Pharm Sci Res. 2016;3(3): 39-44.

4. Astriani Y, Widawati M. Potensi tanaman di indonesia sebagai larvasida alami untuk Aedes aegypti. Spirakel. 2017;8(2).

5. Fuadzy H. and Hendri J., 2015. Indeks entomologi dan kerentanan larva Aedes aegypti terhadap temefos di Kelurahan Karsamenak Kecamatan Kawalu Kota Tasikmalaya. Vektora: Jurnal Vektor dan Reservoir Penyakit, 7(2), pp.57-64.

6. Febryanto R, Hajrah, Rijai L. Potensi Ekstrak daun pisang (Musa textilis Née) terhadap penurunan kadar gula darah. J Chem Inf Model. 2019;53(9):88-99. 
7. Elisabeth V, YamLean PVY, Sri Supriati H. Formulasi sediaan granul dengan bahan pengikat pati kulit pisang goroho (Musa acuminafe L.) dan pengaruhnya pada sifat fisik granul. Pharmacon. 2018;7(4):1-11.

8. Rukminingsih F, Pujiastuti A. Sand granules ekstrak biji alpukat (Persea Americana seed extract) sebagai larvasida alami pemberantas demam berdarah dengue. Jurnal Farmasi Galenika (Galenika Journal of Pharmacy)(e-Journal). 2020 Mar 2;6(1):84-93.

9. Sari, M. dan Khaira IM. Ekstrak daun pepaya (Carica papaya L.) terhadap mortalitas larva nyamuk Aedes aegypty. Epidemika. 2020;1(1):17-23

10. Basri L. Pemanfaatan ekstrak kayu manis (Cinnamomum Burmanii) sebagai larvasida alami untuk nyamuk Aedes aegypti. Global Health Science (GHS). 2018 Dec 31;3(4):6-10.

11. Widyastuti DA, Rahayu P, Dewi LR. Potensi ekstrak sirsak (Annona muricata) sebagai larvasida pengendali populasi Aedes albopictus. Bioeksperimen: Jurnal Penelitian Biologi. 2019 Apr 12;5(1):48-54

12. Arcani NL, Sudarmaja IM, Swastika IK. Efektivitas ekstrak etanol serai wangi (Cymbopogon nardus L) sebagai larvasida Aedes Aegypti. E-Jurnal Medika Udayana. 2017;6(1).

13. Ishak NI, Kasman K, Chandra C. Efektivitas perasan buah limau kuit (Citrus amblycarpa) sebagai larvasida alami terhadap kematian larva Aedes aegypti. PROMOTIF: Jurnal Kesehatan Masyarakat. 2020 Jul 7;10(1):6-13.

14. Kurniawan D, Yuliawati R, Habibi M, Ramlan EE. Efektivitas ekstrak etanol daun sengkuang (Dracontomelon dao) sebagai larvasida alami. Jurnal Penelitian Ekosistem Dipterokarpa. 2019 Dec 31;5(2):79-86

15. Mambang DE, Rezi J. Efektivitas antibakteri ekstrak etanol daun nangka (Artocarpus heterophyllus L) terhadap pertumbuhan bakteri Staphylococcus aureus. Jurnal Agroteknosains. 2018 Dec 4;2(1).

16. Yulianty Y. Uji Efektivitas mulsa daun pisang kepok (Musa paradisiaca L.) terhadap pertumbuhan vegetatif tanaman tomat (Lycopersicum esculentum Mill.). InProsiding Seminar Nasional Biologi 2019. Perhimpunan Biologi Indonesia. 2019. 84-92.

17. Burhan A, Hardianti B, Mujilah M. Uji aktivitas hipoglikemik ekstrak daun pisang kepok kering (Musa paradisiaca forma typica) terhadap mencit jantan (Mus musculus). Media Kesehatan Politeknik Kesehatan Makassar. 2019 Jun 30;14(1):6680.

18. Alifiawati A, Miranti M, Almasyhuri A. Formulasi granul efervesen ekstrak air daun sukun (Artocarpus Altilis (Parkinson ex FA Zorn) Fosberg) dengan perbedaan konsentrasi asam dan basa. Jurnal Online Mahasiswa (JOM) Bidang Farmasi. 2018 May 29;1(1).

19. Nugraheni TP, Rosvita V, Pratiwi HK. Uji aktivitas penangkapan radikal bebas dpph oleh ekstrak etanol daun pisang tanduk (Musa Paradisiaca Var Formatypica) dan daun pisang cavendish (Musa Paradisiaca Var Sapientum). Indonesia Jurnal Farmasi. 2018 Dec 6;2(1):69-74.

20. Purnamasari MR, Sudarmaja IM, Swastika IK. Potensi ekstrak etanol daun pandan wangi (Pandanus amaryllifolius Roxb.) sebagai larvasida alami bagi Aedes aegypti. E-Jurnal Medika Udayana. 2017; 6(6):1-5.

21. Sucipto CD. Manual Lengkap Malaria: Aspek lingkungan vektor malaria, malaria dan kehamilan, pengobatan penderita malaria, pengendalian malaria, insektisida dan formulasi. Litbang Kemenkes. 2019. 178-191.

22. Tina L, Misnawati, Fiifi NG. Uji perbandingan efektivitas ekstrak daun sirih hijau (Piper betle Linn) dengan ekstrak daun pandan wangi (Pandanus amaryllifolius Roxb) terhadap kematian larva nyamuk Aedes aegypti. Preventif Journal. 2018;3:111. 
23. Budiman A, Faulina M, Yuliana A, Khoirunisa A. Uji aktivitas sediaan gel shampo minyak atsiri buah lemon (Citrus limon Burm). Indonesian Journal of Pharmaceutical Science and Technology. 2015 Jun 1;2(2):68

24. Iskandar I, Horiza H, Fauzi N. Efektivitas bubuk biji pepaya (Carica Papaya Linnaeaus) sebagai larvasida alami terhadap kematian larva Aedes aegypty. Eksakta Berkala Ilmu Bid MIPA. 2017;18(01):12-8.

25. Riandi LV, Fahrimal Y, Rinidar R, Hasibuan SP. Potensi daun belimbing wuluh (Averrhoa bilimbi L.) sebagai larvasida alami. Journal of Healthcare Technology and Medicine. 2019 Oct 11;5(2):79-84. 